\title{
CASIMIR JAGIELLOŃCZYK AND THE POLISH GAMBLE, 1445-7*
}

\section{S. C. ROWELL}

\section{Lithuanian Institute of History, Vilnius}

In the history of every nation there are figures who overshadow contemporaries and dazzle the minds of succeeding generations with their Shakespearian grandeur. In the case of late-medieval Lithuania and Poland, two such luminaries are Jonas Goštautas and Cardinal Zbigniew Oleśnicki whose reputations still dominate studies of the fifteenth-century Jagiellonian confederation - and not without reasonable justification. Nowhere is this more apparent than in analyses of Lithuano-Polish relations in the 1440s and the election of Grand Duke Casimir Jagiellończyk as king of Poland. Events too take on a mythic connotation which may be different from their original form and significance. In this case the Polish royal election of 1445-7 came to figure in sixteenth-century accounts of the relationship between Poland and the Grand Duchy as ammunition in the political struggle leading up to the Union of Lublin. ${ }^{1}$ Modern scholarship continues a similar sixteenth-century agenda, albeit with shades of nineteenthcentury national re-creation fervour, focussing on such concepts as the wider-nation state, rather than the dynastic patrimonial polity. Lewicki's 1897 article remains the best account of the election. ${ }^{2}$ There is a tendency to use the terms "Polish" and "Lithuanian" in ways

*This essay forms part of a wider study of the Grand Duchy of Lithuania under Casimir I and IV which is now under preparation. The texts cited below in shortened form will be published in full in the first volume of Casimiriana (Vilnius, 2001). Frequent reference is made to manuscript sources held in Berlin, Geheimes Staatsarchiv, Preussischer Kulturbesitz, OBA [Ordensbrief Archiv] and OF [Ordens Folianten].

${ }^{1}$ Dnevnik liublinskogo seima 1569 goda. Soedinenie VKL s Korolevstvom pol'skim, ed. M.O. Koialovich (St Petersburg,1869), 65, n.1, 79, n.1.

${ }^{2}$ A. Lewicki, 'Wstąpienie na tron polski Kazimierza Jagiellończyka', Rozprawy i sprawozdania z posiedzień wydz. hist.-filozof. Akademii Umiejętności xx (1897), 1-40; O. Halecki, Dzieje Unii Jagiellońskiej, I: w wiekach średnich (Kraków,1919), 352-64; L. Kolankowski, Dzieje Wielkiego Księstwa Litewskiego za 
which confuse the divisions inherent in both the Grand Duchy of Lithuania and the Crown of Poland. When we read that the "Poles" did this, or that the "Lithuanians" protested, we must ascertain which Lithuanian or Polish group we mean. The aim of this survey of events between the convention of Sieradz (April 1445) and Casimir's coronation in June 1447 is not to deny the importance of the Kraków and Vilnius grandees, but to broaden the traditional interpretation and question the accuracy of clichés which have been propounded since Długosz compiled his chronicle, by refocussing attention on the Jagiellonian camp in order to balance the interpretation of both the Lithuanian and Polish 'political nations'. While the main argument expounded by Długosz, namely that the Grand Duchy was subsidiary to the Crown of Poland and that Jogaila's line ruled by grace of the Polish nobility, is clear, the chronicler himself presents arguments in secondary scenes which can be used to question the most extreme of his Małopolskan pro-szlachta declarations. The same men who claim that Jogaila and his sons are their creation also recognise, occasionally, the exceptional status of the Lithuanian dynasty. As ever, the complexity of using Długosz's chronicle as a primary source lies not in detecting falsehood but in sensitivity to what the American proletariat calls 'attitude'.

In the winter of 1444-45 Casimir led a Lithuanian army against Muscovy to lay siege to the towns of Kozelsk, Kaluga and Mozhaisk in revenge for a Muscovite-provoked Tatar raid on Viazma and Briansk. ${ }^{3}$ His main commanders in the field were Sudewoj (Valimantaitis, a kinsman of Kęsgaila), Radvila, Andrius Sakaitis and Mikalojus Nemira. It was in the midst of this campaign that news of his brother Władysław I and III's death in battle with the Turks at Warna was brought to the Grand Duke at Polotsk by the king's comrade-in-arms Jan of Sienko in December 1444 or early 1445. Jan, who was sent to Casimir by Crown counsellors, was not only a cousin of Bishop Oleśnicki and companion of King-Supreme Duke Władysław, but also an experienced negotiator with the Lithuanian gentry. He had fought against Švitrigaila in Rus' and ex-

Jagiellonów, I: 1377-1499 (Warsaw,1930), 240-51; A. Prochaska, 'O rzekomej unii z 1446 r.', Kwartalnik Historyczny [henceforth KH] xviii (1904), 24-32; B. Dundulis, Lietuvos kova dèl valstybinio savarankiškumo XV amžiuje (Vilnius,1993), 180-9; W. Fałkowski, Elita władzy w Polsce za panowania Kazimierza Jagiellończyka (1447-1492) (Warsaw,1992), 45-51. Nothing is added by the posthumous publication of H. Łowmiański, Polityka Jagiellonów, ed. for publication by K. Pietkiewicz (Poznań,1999), 215-22.

${ }^{3}$ Polnoe Sobranie Russkikh Letopisei XII (Moscow,1965), 63. 
hibited pro-Žygimantian leanings. ${ }^{4}$ His experience of the Grand Duchy's politics, therefore, was connected with the 'Vilnius', rather than the provincial factions. This point is worth bearing in mind as we examine Lithuano-Polish relations in the fifteenth century: the main actors on our stage appear to be unconnected directly with the 'opposite side', but often they are linked by informal personal connections born of experience (that is, service), rather than by birth, property or kinship.

Certainly, Władysław's death could have come at a better time for the Polish barons. In September 1444 the latter, convened in a sejm at Piotrków, wrote to the king, reminding him how they had accepted him and his brother as 'heredes, naturales dominos et paterni splendoris veros successores'. They argued that sharing a prince (in this case with Hungary) is harmful because of the discord which arises during his absence (a point which tends not to be appreciated fully by modern scholars, who seem to interpret opposition to sharing a ruler as simple patriotism). In particular they cite recent calamities which have befallen Poland: the Tatars have ravaged Rus', especially Podolia; Casimir and his Lithuanians with Tatar help have attacked Mazovia and Lukow in Crown Rus'; Mikołaj of Raciborz and Bolesław of Opole have created havoc in the western borderlands. Jan Pilecki and the bishop of Wrocław bear the Piotrków Sejm's report to the king and envoys are sent to Casimir and Bolesław to make peace or a truce until Władysław returns. ${ }^{5}$ The political situation in Małopolska and the territories where its interests were directly involved (such as Hungary, Silesia, Moldavia) was hardly propitious, especially if a complete break with the policies of the past fifty years were to be required. The economy also seems to have been in considerable disarray with a Crown debt of 58,000 grzywny. Kraków appears to have been suffering from inflation and a devalued silver currency. The University preacher Jan z Ludziska in his address to Casimir in June 1447 would speak of agricultural conditions worse than the servitude of ancient Egypt and the archbishop of Gniezno complains of excesses on the part of Crown servants, a situation which is reflected in the protest of village women made during the ceremonies surrounding the royal coronation. ${ }^{6}$ In short,

${ }^{4}$ Polski Stownik Biograficzny [henceforth PSB], X (Wrocław-WarsawKraków, 1962-64), 475-6.

${ }^{5}$ Codex epistolaris saeculi decimi quinti [henceforth CESXV], I.1 (Kraków,1876), No. 125, pp. 140-4 and below.

${ }^{6} \mathrm{~J}$. Pelc, Ceny w Krakowie w latach 1369-1600 z 16 diagramami (Lwów,1935) [= Badania z dziejów spotecznych $i$ gospodarczych, xiv], 2: ducat in 
the Polish barons, especially those of Małopolska were under attack, social regulation was weak and the Polish regents unsure where to turn for help. Władysław, however, did not return.

For Casimir too the news was not of the timeliest. However, the years of open revolt in Žemaitija and Rus' were over (with discontent smouldering now rather than blazing) and relations with both the Order and the towns of Prussia thriving. Casimir was not without rivals (as the course of events in 1445-7 illustrates), but his position and that of his 'court' party (Goštautas and friends) was more stable than it had been earlier in his reign. The adolescent grand duke was climbing slowly out of his "protectors" shadow. The Vilnius government could risk waging war on Mazovia and Moscow.

In economic terms the Grand Duchy was growing in strength. The impulses gained by western commerce in Vilnius and Kaunas and the links with Gdańsk and, to a lesser extent, Königsberg, not to mention the continued importance of the Dvina trade route to Livonia allowed the grand duke to payroll his noble supporters. The history of Lithuanian commerce in the first half of the fifteenth century, especially between 1430 and 1447 remains unclear. Assumptions are made from relative silence that such trade was either weak or non-existent, especially in Žygimantas's day. ${ }^{7}$ The documentary base

Polish groats, 48 in 1440, 34.33 in 1446; price of beer rises (p.28), as does that of herring (p.38), pepper (p.116) and cloth (p.50); price of pork falls (p.36); Crown debt: F. Bujak, 'Mowa Jana z Ludziska do krola Kazimierza Jagiellończýka z roku 1447 i zagadnienie niewoli w Polsce ówczesnej’, Wybór pism, II: Z dziejów społecznych i gospodarczych Polski X-XX w. (Warsaw,1976), 110. Sermon text: CESXV III (Kraków,1894), No.8, pp.13-16. In a rather intoxicated article in Ateneum Wileńskie vi (1929), 8-15, Feliks Koneczny argued that the reference to slavery was relevant to Lithuania rather than Poland. Bujak confronts this assertion with other evidence. If either researcher had paid attention to the sermon addressed to Archbishop Wincenty of Gniezno at the same time (it follows on from the address to Casimir in the Jagiellonian manuscript), he would have noticed the same reference to slavery there (in a purely Polish context). Wincenty's sermon: Biblioteka Jagiellońska MSS 126, p.113f.. For the villagers' protests at the requisitioning of cattle, which Długosz turns against Casimir, see Długosz, 34.

${ }^{7}$ Payrolling supporters with land in the 1440s and later with the proceeds of trade taxation is clear from the so-called 'kniga danin' which survives in the Lithuanian Metrica: Lietuvos Metrika. Knyga Nr.3 (1440-1498) Užrašymu knyga 3, ed.L. Anužytè and A. Baliulis (Vilnius,1998), 19-58; Akty litovsko-russkogo gosudarstva, I: (1390-1529) (Moscow, 1899), 19-51. An assumption that trade was halted in the years 1430-40 is reflected in M. Biskup, Stosunek Gdańska do Kazimierza Jagiellończyka w okresie wojny trzynastoletniej 1454-1466 (Toruń,1952), 13-14. 
for such studies is meagre. However, the records which do survive allow one to justify the conclusion that, although trade in the years of civil war following Vytautas's death was not strong enough to meet the exaggerated demands of financing Žygimantas's conflict with Švitrigaila fully, economic life during Casimir's early reign, especially trade with Gdańsk began (or continued) to thrive. The route to Tartary, tariffs for various furs (marten, mink, beaver) and regulations concerning wax and the import of foreign cloth via Kaunas and Vilnius, linking up with merchants from Kraków, Wrocław, England, Flanders and Holland were brought for discussion with the Grand Master by Casimir's embassy (led by the grand duke's marshall and certain Vilnius burghers). ${ }^{8}$ Regulation of the Prussian trade became more frequent from 1444 or so, with complaints over mistreatment of merchants in and from Vilnius and Kaunas, dealing with excise, quality control (of poor English cloth imported via Holland and Gdańsk to Kaunas) increasing. ${ }^{9}$ Although the Grand Duchy could certainly not rival the Teutonic Order seriously as a market for the goods of Prussian merchants, her western towns (Kaunas, Vilnius, Brest, Grodno, Mogilev) were firmly integrated into the Polish and Prussian eastern trade network - linking up with Kraków, Wrocław, Poznań and perhaps more importantly, considering Mazovian interests, Warsaw.

Merchants with interests in Kaunas and Vilnius included councillors of the Prussian towns (Arnd Finckemberg, Heinrich von Staden) who were delegates to the Ständetage, and the Lithuanian towns (Goschewicz of Vilnius). ${ }^{10}$ Merchants and administrators of merchant towns acted as ambassadors, au fait with political developments.

Before continuing with our account of events in Poland and Lithuania during these complicated years, we should try to step outside the narrow confines of the Jagiellonian monarchy to understand the con-

${ }^{8} \mathrm{OF} 15,212-6$.

${ }^{9}$ OF 16 pp. 1099-1100, 1102-03, 1130, 1131, 1161-3ª ; OBA 28523; Gdańsk,

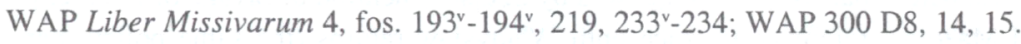

${ }^{10} \mathrm{Gdańsk}$ councillors: von Staden - Ms: Gdańsk, WAP, Liber Missivarum 4, fo.194, 219, Akten der Ständetage Preussens unter der Herrschaft des Deutschen Ordens, ed. M. Töppen, II (Leipzig,1880, Aalen,1974), 7, 55, 66, 110, 208, 233, 256; Finckemberg - ibid., 501, OF 16 p.1234; Vilnius councillor and merchant, Goschewicz - see S.C. Rowell, 'Winning the living by remembering the dead? Franciscan tactics and social change in fifteenth-century Vilnius', Tarp istorijos ir būtovès. Studijos prof. Edvardo Gudavičiaus 70-mečiui, ed. A. Bumblauskas and R. Petrauskas (Vilnius, 1999), 87-121. 
text in which Casimir was wooed by Kraków and which influenced both Polish and Lithuanian responses to the interregnum.

The Duchy of Mazovia, as we have seen, was in conflict with Lithuania. In an embassy to the Order, the Gewerbe zcum Prewsschenmarkte of August 25 1444, Casimir remarks on the outcome of the Podolian war. Similar themes were expressed by Bolesław IV in his June embassy to the Knights when he informed the Order of Casimir's war over Drohiczyń and other 'stete, dorffer, slosser' and complained (without grounds, the Grand Master replies) that the Knights had helped Casimir. ${ }^{11}$ Bolesław turned to Oleśnicki and the Polish lords for mediation with Casimir. ${ }^{12}$ Some time in 1445 Bolesław IV married Barbara, daughter of Olelkaitis of Kiev. ${ }^{13} \mathrm{Al}$ though the exact date of this marriage is not known, a hypothesis to the effect that it was connected with political events in Lithuania and Poland seems tenable. With Mazovia defeated by Casimir's forces and its duke married to the daughter of one of the grand duke's supporters, dynastic issues became complicated further. Mykolas Žygimantaitis, Casimir's second cousin and rival was married to his third Mazovian bride, Katarzyna, daughter of Siemowit IV. ${ }^{14}$

Mykolas' support was restricted to his affines in Mazovia and the Oleśnicki party in Kraków which saw in him a convenient means of weakening central authority in the Grand Duchy and by extension in Poland. Such a point of view is not 'anti-Lithuanian' (the same policy (of supporting the rivals of a regional establishment) applied in Poland cannot be accused of working against the Grand Duchy) so much as anti-monarchical, or in certain circumstances, anti-Vilnius. The Teutonic Order resisted attempts to embroil the Knights in both Mykolas Lithuanian campaigns and Casimir's counter-attacks by pleading that the Treaty of Brest required the Order to keep its roads open and not to aid grand-ducal enemies. The powerful discontent

${ }^{11} \mathrm{OF} 15, \mathrm{p} .280-82,134-5$.

${ }^{12}$ CESXV I.1 No. 124, pp.138-40: Oleśnicki's letter to Casimir sent from Bodzanczin (Sandomierz area). The letter is not dated but 1444 seems to fit certain criteria better than 1443, as suggested by Szujski: mention of ravage of Drohiczyn and Mazovia, reference to truce until Władysław returns (the same policy mentioned in the Piotrków sejm letter of September 1444 - see above n.3).

${ }^{13} \mathrm{~J}$. Tęgowski, “Anna i Barbara księżne mazowieckie z XV wieku. Przyczynek do genealogii Piastów mazowieckich", Spoleczeństwo i polityka do XVII wieku. Księga pamiatkowa ku czci Profesora doktora Wacława Odyńca w 70-lecie urodzin (Olsztyn,1994), 100-101.

${ }^{14}$ Mykolas was married in turn to Anna (d.before 1435), daughter of Siemowit IV; Ofka (d.1436), daughter of Jan, sister of Bolesław IV; Katarzyna (d.1475) daughter of Siemowit IV. 
which swept through Žemaitija in 1441 and 1442, culminating in battle between Mykolas supporters, led by Kantautas, and Casimir's army, was neutralised by the issue of a charter for Žemaitija and the division of the starostaship between Kantautas and Kęsgaila. Further attempts at reviving the competition between the court and country parties in 1444 and 1446 would come to nought ${ }^{15}$.

The Teutonic Order should have been expected to take advantage of regional conflicts, especially of dissension within and between Poland and Lithuania. There were even several deliberate attempts on the part of Mazovia and Mykolas Žygimantaitis to draw them into action. However, the Knights' realm was itself embroiled too deeply in disputes with its neighbours and subjects to exploit the situation fully. Indeed, the Order's own weaknesses were exploited by Casimir and later perhaps by the archbishop of Gniezno.

The main political and economic problem facing the Order from 1445 was the strength of the Prussian League and its leading members' refusal to pay the poundage tax, or Pfundzoll. In 1445 Chełmno and Torun declined to pay this duty to the Knights on the basis that, as the holders of a Chełmno Charter, they were free from all such exactions. The Knights hoped to solve the problem amicably, since these towns had a strong influence on the smaller Prussian towns. The Grand Master referred the question to Magdeburg for deliberation. The Torun commander was so poorly financed that he had no money for salt and fish for his brethren and took out loans with the Jews of Nessau. The dispute was brought to the attention of the king of the Romans and the Holy See. The League was a threat to the Order's security, both financial and military. In April 1446 Bishop Franz of Warmia denounced Bund as being "widder alle gotliche und naturliche Rechte", and against the letter of papal and imperial charters. On June 19 the commander of Gdańsk announced overoptimistically that the smaller towns were ready to leave the Bund; the commander of Torun reported that Strasburg will do as Chełmno and Torun do. And so it came to pass: on July 17 at the Marienwerder diet, the towns rejected all plans for dissolution of Bund. Accusations of agreement-breaking would prove embarrassing not for the Bundists but for the Grand Master. ${ }^{16}$

${ }^{15}$ S. C. Rowell, 'Rusena karas Žemaičiuose: keletas pastabu apie 1442 m. privilegijos genezes', Žemaičiu praeitis viii (1998), 5-11; idem, "Bears and traitors, or political tensions in the Grand Duchy ca. 1440-1481", Lithuanian Historical Studies 2 (1997), 32-7

${ }^{16} \mathrm{E}$. Lüdicke, 'Der Rechtskampf des Deutschen Ordens gegen den Bund der Preußischen Stände 1440-1453', Altpreußische Forschungen xii (1935), 10; J.Voigt, 
The elector of Brandenburg was in dispute with the Order over the New Mark and demanded payment of 15,000 gulden; matters here did not improve until mid-summer; only relations with Stolp were friendly. In 1446 the conflict with Brandenburg increased over the building of a bridge across the Warta near Santok. ${ }^{17}$

In economic terms by 1446 only Gdańsk (of independent inclinations) had good links with England, while connections between the Ordensstaat and France and the Low Countries were weak. Relations with Denmark were also cool. It is no wonder that the Order sought to extend its trade with the Grand Duchy. In 1447 new links were established with England, France, Flanders, Holland, Denmark, the Hansa, Spain and Portugal. ${ }^{18}$

The Livonian branch of the Order was in a state of war with Novgorod, which was under the military control of Lengvenaitis, Casimir's kinsman and competitor. Casimir maintained a policy of considered neutrality in this conflict, despite papal admonitions to intervene (on the Knights' behalf). Casimir rejected this plea, but the Knights intercepted Gdańsk weapons merchants en route to Lithuania. ${ }^{19}$ Livonian relations with Polotsk were strained.

Cross-border raids between north-eastern Prussia, Livonia and Lithuania (both Žemaitija and Lithuanian Rus') disrupted relations between the two states. Refugees fled to both sides - especially Curonians who left Nehrung for Žemaitija, to the dismay of the Order's leadership. ${ }^{20}$

As for the Grand Duchy's eastern borders with the Grand Duchy of Moscow and the 'Republic' of Novgorod, the former was caught up in civil war and the latter faced the threat of war with the Teutonic Order. It was Casimir who exploited the dirficulties facing Vasily Vasilievich and not vice versa. ${ }^{21}$

In the Sieradz Sejm of April 23 1445, Oleśnicki suggested electing Casimir as king, since it would be better for a kinsman rather than an enemy to be on the throne should Władysław in fact return. In

Geschichte Preussens von den aeltesten Zeiten bis zum Untergange der Herrschaft des Deutschen Ordens, VIII (Königsberg,1838), 77-80, 97-106.

${ }^{17}$ Voigt, Geschichte VIII, 77-106.

${ }^{18}$ Ibid., 115; OF 16, 586.

${ }^{19}$ CESXV, II (Kraków,1891), No. 302, p.450-1: Eugenius IV to Casimir, Oct. 3 1444; OF 16, p. 1163-1163a, Dec. 21 Thomas Samedh and weapons shipment, also OBA 9268 (Feb. 1 1447). For Novgorod campaign see below p. 26.

${ }^{20}$ Liv-Est und Kurländisches Urkundenbuch nebst Regesten, ed. F.G. von Bunge, X (Riga-Moscow,1896; Aalen,1981) [henceforth $L U$ ], 128, 170, 171; OF 16, 1136

${ }^{21}$ Kolankowski, Dzieje, 261-3. 
Oleśnicki's own words (as related by Długosz), Casimir was "non hostis sed germanus, non extraneus sed naturalis". ${ }^{22}$ This recognition of Casimir as natural heir to the Polish Crown conforms with the 1444 Piotrków letter to Władysław but contradicts (naturally enough) Oleśnicki's other public view of the Jagiellonian house, expressed most clearly also by Długosz. The Queen Mother, Sonka appreciated the bishop's argument and four envoys, namely Piotr Oporowski of Lęczyca ${ }^{23}$, Piotr Chrząstowski (Małopolska) ${ }^{24}$, Piotr Szamotulski25 and Mikołaj Czarnocki, were sent to invite Casimir to Piotrków on August 25. These men, whom Fałkowski calls men of rank but lacking public office, were somewhat more than any old aristos: they represented a spread of Polish duchies (Wielkopolska, Kujawy, Małopolska), had accumulated considerable experience of dealing with both Lithuania and the Teutonic Ordensstaat, and were proven supporters of Jogaila's sons. The very decision to consider Casimir was completely in keeping with the acts of union acknowledged by that generation of noble functionaries (for the last time as recently as 1440). This was no new whim or favour but their duty.

In May 1445, the Queen Mother, Sonka, went to Hungary to try and persuade the Hungarians that Władysław was still alive and urge them not to proceed to a new election. In her letter to the Magyar estates convened at Pest (from April 26) the Queen notes how Casimir has heard from a Lithuanian merchant that his brother is alive and has sent envoys to confirm this. They have promised to return by June $24 .{ }^{26}$ What concerns us here is not so much whether Casimir did indeed receive such news from a merchant (later Oleśnicki notes similar rumours spread by Italian merchants ${ }^{27}$ ) but that he was involved in at least one delaying tactic together with his mother.

22J. Długosz, Historiae polonicae V (lib. xii), ed. A. Przezdziecki (Kraków,1878), 3-4 [henceforth. Długosz]; F. Piekosiński, 'Tłumaczenia polskie statutów ziemskich', Archiwum Komisyi prawniczej, III (Kraków,1895), 123.

${ }^{23}$ Piotr Oporowski (c.1405-67) of Łęczyca acted as guarantor of the 1434 peace with Žygimantas Kęstutaitis, appended his seal to the Treaty of Brest (1435), confirmed Władysław III's charter at the Piotrków Sejm of 1438 and in 1439 lent the king 1,000 florins to support Casimir's candidature to the Bohemian throne. He accompanied Władysław to Hungary. His wife was a Chrzastowska: PSB XXIV/1, 139-42

${ }^{24}$ J. Długosz, Historiae polonicae IV, ed. I. Żegota Pauli (Kraków,1877), 627: his brother went to Hungary with the king in 1440.

${ }^{25}$ From Wielkopolska, later a close adviser to Casimir after the coronation: Wielkopolski Stownik biograficzny (Poznań,1981).

${ }^{26}$ CESXV I. 2, p.4.

${ }^{27} \mathrm{CESXV}$ I. 2, p. 11 
On June 13 the Polish nobles established a truce with the Silesians to last until June $24,1446 .{ }^{28}$ The dispute was suspended, but not resolved. It was stipulated that if Władysław returned to his kingdom, new negotiations would be held with the Polish council.

In June 1445 Casimir renewed his treaty with Hospodar Stefan of Moldavia, guaranteeing mutual defence against their common enemies, except King Władysław. ${ }^{29}$ It seems that both the Polish and Lithuanian sides were doing their best to tidy up possible sources of irritation. June 1 is the date of Casimir's confirmation of land grants made by Švitrigaila to his faithful counsellor Pashko Dakhnovich. ${ }^{30}$ It would seem, therefore, that relations between the Vilnius and Rus'ian parties within the Grand Duchy were becoming or had already become closer and more constructive.

In summer 1445, between April 23 and August 25 Oleśnicki wrote to Bishop Mathew of Vilnius asking him to bring pressure to bear upon Casimir to accept the Polish crown, issuing a veiled threat to the grand duke's position should he refuse and another ruler be elected. After Casimir's acceptance a noble convention was to appoint unanimously a ruler (rector) for Lithuania to compensate for the king's absence. There is no reason to draw Dundulis's conclusion that this proposed 'rector' would be Mathew. Oleśnicki mentions the plan to the bishop of Vilnius because he is of a more senior generation than most of the Lithuanian council (taking into account his election as bishop of Žemaitija in 1417 and translation to Vilnius in 1422) and can remember the 'good old days' of Jogaila and Vytautas. Throughout negotiations over the fate of the Polish Crown more active participation came from the archdeacon of Vilnius (Casimir's faithful servant), rather than the bishop, who acted as head of the Lithuanian Council. Here I would stress the conclusion that Oleśnicki was not operating in a theoretical vacuum, but entirely in keeping with the acts of union, whereby the election of a ruler of one or other realm required the consultation of both sides. The absolute

\section{${ }^{28}$ CESXV I.2, p.343-5.}

${ }^{29}$ LM 5, p.255-6, No.138; on dating to 1445 see I. Czamańska, Moldawia $i$ Wołoszczyzna wobec Polski, Węgier i Turcji w XIV i XV wieku (Poznań,1996), 100 and n.309. Eliasz died 1444 and Stefan renewed the 1442 agreement with Lithuania; Casimir checks his southern border. The fact that Władysław is mentioned in the treaty as living, when in fact he was dead, need not require us to reject this dating since in May 1445 Casimir was maintaining publicly that his brother was still alive.

${ }^{30}$ Archiwum ksiqżąt Lubartowiczów-Sanguszów w Stawucie I (Lwów,1887),

134; O. Halecki, Ostatnie lata Świdrigietty $i$ sprawa wołyńska za Kazimierza Jagiellończyka (Kraków,1915), 72. 
political polarisation depicted in Polish and Lithuanian studies of this period is not based on an unbiased examination of all surviving evidence.

On August 25, 1445, Sonka and six hundred barons and prelates of Poland gathered at Piotrków; where the Polish envoys announced that Casimir would deliver his reply through his own envoys. These were Archdeacon Martin of Vilnius and Jonas Nemira. ${ }^{31}$ These men took part in other 1445 embassies - to the Teutonic Order. ${ }^{32}$ The seventeenth-century historian Kojalowicz says that Radvila and Kęsgaila were present in Piotrków. ${ }^{33}$ This may be the result of the seventeenth-century understanding of which families 'ought to have' figured in such a delegation. However, it may be a reflection of other sources. This point is worth bearing in mind since it counters the chauvinistic tradition of Lithuanian scholarship which portrays interregnum events simply in the context of 'national-ist' aspirations. We know from the records of Kraków University that Goštautas and his wife, together with Kęsgaila and Helena Kęsgailienè were present in the city in 1445, when they are listed as patrons of the Jagiellonian foundation. From the records of the Confraternity of St Mary in St Mary's church, we know that Astik (Radvila) and his wife Anna along with Butrincko (Butrimas) Kęsgailaitis ("her Brutrincko zon pallatini terre Semogite") became members of this important Cracovian religious society. ${ }^{34}$ Members of the Lithuanian noble junta were willing to exploit Polish culture, its infrastructure and its privileges but did not wish to foster competition with its representatives inside the Grand Duchy itself - as the May 21447 Charter makes crystal clear (see below). A certain amount of interaction, rather than simple opposition, on the part of Lithuanian and Polish nobles is discernible.

${ }^{31}$ From Novgorodok district, brother of one of the commanders of Casimir's 1444-5 campaign against Moscow, later namestnik of Vitebsk (1466), Smolensk (1467), marshall (1471).

${ }^{32}$ Długosz V, 6-7; LU X, Nos. 170, 171, negotiations of September 25; Martin of Szadek was the recipient of favours from Casimir - Kodeks dyplomatyczny katedry $i$ diecezji wileńskiej, ed. J. Fijałek and W. Semkowicz, I (Kraków,1948) No.139, p.157. OBA 8875 (sejm settles the Order's dispute with Michał of Golancz - between Bydgoszcz and Poznań), 8897.

${ }^{33}$ Albertas Vijūkas-Kojelavičius, Lietuvos istorija, tr. L. Valkūnas (Vilnius, 1989), 483.

${ }^{34} \mathrm{~W}$. Semkowicz, 'O litewskich rodach bajorskich zbratanych ze szlachtą polską w Horodle roku 1413', Lituano-slavica posnaniensia. Studia historica, iii (1989), 30; Rowell, 'Winning the living', 97-8, esp. n.28. 
In the 1440s the number of students from Lithuania (mainly Vilnius) is more or less equal to that of the 1410s, 1420s, 1460s, 1470s, and significantly higher than that for the 1430s [6] and 1450s [8]. In 1443 Goschewicz's son Andreas, future canon and bishop of Vilnius matriculated in the Jagiellonian university. ${ }^{35}$ The grounds were laid to make the exclusion of (foreign) competition from the Lithuanian bureaucratic aparatus possible by training up native potential.

At Piotrków the Lithuanian envoys stressed the distraught nature of the grand duke and Casimir's unwillingness to rule Poland while there was still hope that his brother was alive and suggested that the regents appointed during his brother's minority and later to rule during Władysław's absence continue to govern the kingdom. This position suggests both fraternal concern and a gambler's reply to Oleśnicki's attempt to lead the Lithuanian council into temptation. It is an example of counter-blackmail on Casimir's part with regard to the Małopolskan nobility - by forcibly reminding them of a situation (i.e., regent government) which was unfelicitous, as they themselves had sought to inform Władysław in September 1444, and maintaining the Lithuanian bluff begun by the grand duke and his mother. It is wise to agree with Fałkowski's conclusion of blackmail, whilst distancing oneself a little from his assessment of the background scene. The situation in the Grand Duchy itself was far from unambiguously favourable or unfavourable to Casimir and the faction most closely associated with him. ${ }^{36}$

The sejm was disatisfied with the suggestion that the status $q u o$ be maintained. One suspects that Oleśnicki was in no strong position in relation to his fellow oligarchs. The bishop was faced with opposition in Wielkopolska and resistance in his attempt to annex Silesian territory to the see of Kraków (Siewier). It was decided to send another delegation to Casimir to announce his election, ask him to assume the Regnum Poloniae and come to his coronation. After a certain delay he should then take up the reins of government. The envoys selected for this task were Wincenty Archbishop of Gniezno, Zbigniew of Kraków, Władysław bishop of Wrocław, Jan Tęczynski, wojewoda of Kraków, Lukasz Górka, wojewoda of

${ }^{35}$ Students and their origins: [Vilnius 12, Kaunas 2, Soleczniki 1, Merecz 1, Lyda 1, Wawerka 1 [1440-7, with one more in 1449] in V. Biržiška, Lietuvos studentai užsienio universitetuose XIV-XVIII amžiais ed. M. Biržiska and suppl. A. Šapoka (Chicago,1987), 37-41. We should bear in mind that the 1430s were a decade of civil war within the Grand Duchy and the 1450s dominated in Poland by the Thirteen Years' War.

${ }^{36}$ Fałkowski, Elita, 46-7. 
Poznań, Jan Lichiński, wojewoda of Brześć, Piotr Odrowąz wojewoda of Lwów (a name which will appear again), Jan Koniecpolski, Chancellor of the Kingdom of Poland. ${ }^{37}$ The envoys, like those despatched from Sieradz in April, represent the major duchies of the Kingdom. Like the members of that delegation these men were no strangers to negotiations with the Lithuanians. The archbishop of Gniezno and Tęczyński had appended their seal to the 1437 union with Žygimantas Kęstutaitis and all, except Lukasz Górka, had witnessed the Union of 1438. Górka, however, had taken part in Władysław's Hungarian war. He was not without Jagiellonian connections.

On October 17 the aforementioned envoys (with the exception of Władysław of Wrocław) headed by Sonka, who had not been invited but came nonetheless, "impulsa materno affectu", to talk her son into accepting the crown, arrived in Grodno where Casimir and the Lithuanian lords welcomed them. Wincenty gave an address referring back to Jagiellonian beginnings in Poland, saying that the Polish grandees could have elected Sigismund and John of Luxemburg, William Habsburg or the dukes of Silesia or Mazovia, but they chose Jogaila - so as to spread Christianity, make common cause against the Teutonic Order. They married Jadvyga Jogailaite to Frederick of Brandenburg to get a male heir, but later selected one of Jogaila's two sons as king. In order to avoid bloodshed (a point of view expressed by Długosz which other sources bear out, although it is not the only possible interpretation of events of 1440), they sent Casimir to Lithuania. The barons at Sieradz elected Casimir and wanted to crown him on December 5 at Kraków, otherwise they must elect another candidate in order to prevent "varia divisionum monstra", since Władysław is almost certainly dead.

Casimir deliberated in private "cum suis" for several days. According to the Lithuanian account of this meeting, the Polish herren asked him 'das er in sein vaterliche erbe cziehen das konigrich zcu Polan annemen und konig werden welde' ${ }^{38}$ Casimir ostensibly feared for his brother; the Lithuanians are reported as having been afraid lest the 'horrenda tempora' of Vytautas and Žygimantas might return if Casimir left for Poland and that they would lose the liberty they had won. ${ }^{39}$ The image of Vytautas and his brother as tyrants became fixed in fifteenth-century Polish writing. However, anxiety on the part of the new court party in Vilnius is not beyond belief

${ }^{37}$ Długosz, 6-7, CESXV, 3 No.1.

${ }^{38}$ OBA 9035.

${ }^{39}$ Długosz, 10-11. 
(after all, that party had so hated Žygimantas that they had murdered him), especially as regards the continuing disharmony between court and local factions in Žemaitija. Fear of revenge from Mykolas - cited here and confirmed by the Order's information - and of the loss of Lutsk was reasonable, as was insecurity over the as yet unclarified ambitions of Lengvenaitis. The Poles suggested not to fear, for they and the Lithuanians would elect 'personam illis et Ducatui Lithuaniae utilem et gratam', or they would permit Casimir to 'preside' in the Grand Duchy, while another candidate acceptable to both Casimir and the Poles be elected as king, 'concordiam inter utraque dominia servaturus', or Casimir himself be permited to occupy both thrones. In the presence of Casimir and his mother (again, note the family solidarity), the Poles demanded he accept but deign to agree that Casimir should hold a sejm for 'Lithuania, Žemaitija and Rus' in Lithuania to discuss matters and send a final answer by Jan. 61446 and if yes, come to Kraków on February 27, 1446, unless Władysław be proven living.

Another breathing space was won - for the Kraków barons to realise the weakness of their own position. Lithuania, Žemaitija and Rus' were indeed split over which candidate would best fit their interests: Casimir, Švitrigaila, Mykolas or Lengvenaitis. In early November, judging by the number of southern Rus'ian counsellors who foregathered at Lutsk, Švitrigaila and his supporters were deciding on their response to the election question. On November 30, 1445 a council of Lithuanian nobles was held in Vilnius. It was attended by Švitrigaila (fresh from Lutsk), the bishop of Vilnius, Olelko and all his sons and all other dukes and nobles from Lithuania, Žemaitija and Rus' ${ }^{40}$ The nobles urged Casimir to remain in his ancestral home, while the Grand Duke stressed that his brother might still be alive:

so hilt her einen tag uf sent Andres tag czur Wille, herczog Swidergal, der herre bisschoff van der Wille, herczog Lelky mit alle synen Isonen/, alle andrer herczogen und herrn us Littawen, Rewsen und Samagitten bey em waren und en boten, das er bey em blebe, do gelobte er en er welde bey en bleiben, wen das alswol sein vaterlich und seinen elderbeten erbe were und ap ymands anders vorbrachte. So hat er und vom alle werhaftige czeitunge deas sein bruder nach lebe und frisch und gesund sey und dammals wil er in synen stal nicht sitczen. ${ }^{41}$

${ }^{40}$ Lutsk: Halecki, Ostatnie lata, 76, no. 124; Vilnius meeting: OBA 9035

${ }^{41}$ OBA 9035. 
On December 16 the commander of Memel reported to the Grand Master that he had sent a spy to Žemaitija. Mykolas favourite (liephaber) from Mazovia, Bulddaen, reports that three embassies had been sent to Jurgis Lengvenaitis in Moscow, but he had refused grand-ducal office. It is not clear when or by whom these delegations were sent. Dundulis suggests that approaches had been made before the Vilnius sejm (logistics would support such a dating, although they do not connect the embassies with the sejm itself - unless the aim was to invite him to attend, like Švitrigaila) and that the instigator was someone from Goštautas's supporters ${ }^{42}$. It would be more likely that the plan was devised by Goštautas' and Casimir's rivals. According to the Order's source, the Rus'ians wanted to accept Lengvenaitis, as did certain Žemaitijans, although half of the Žemaitijans (presumably Kesgaila's party) wanted Casimir. By early 1446 Lengvenaitis would be restored his patrimony and thenceforth be Casimir's ally (see below). Rumours abounded that Poles would invade with Mykolas and that Lengvenaitis would join them. Bulddaen will go to Mykolas and return in three weeks; two arrivals from Žemaitija cannot say whether the duchy is calm or not. On January 1, 1446 the commander of Memel reported that Kantautas and his Žemaitijans were in Trakai to join forces with certain Lithuanians who favoured Mykolas. Mykolas promised not to take revenge for his father's murder (i.e., Długosz may not err in his claim that there was such a fear in the Grand Duchy). However, the exiled Kęstutid found no wide base of support.

Mikołaj of Raciborz made peace with Oleśnicki and returned Siewier to the bishop's control.

The antagonism virulent between various sections of the Lithuanian nobility, most graphically illustrated by events in Žemaitija was not necessarily injurious to Casimir himself. He could use such disputes to win leeway from his own courtiers such as Goštautas and strengthen his dynastic policy line (with his mother's support in Poland and his uncle Alšèniškis's aid in southern Lithuanian Rus'). While we must be cautious of speaking in terms of Casimir's rule when dealing with his first years as grand duke, after five years in Lithuania the stripling had developed considerable skill in manoeuvring and manipulating conflicting parties within his realm. From the end of 1444 we might discern Casimir's own strong political thread (spun with his mother's assistance) in the court-country weft. This is often undervalued by the political theorist school of research.

${ }^{42}$ Dundulis, Lietuvos kova, 183. 
Before making a final decision Casimir and his council needed to check their borders - in both the literal and metaphorical sense. The court party needed to ascertain the likely reaction of various parts of the Grand Duchy (Žemaitija, Polotsk, Podolia) and their neighbours (the Teutonic Order, Rus') to Casimir's change of status. In winter 1445-46 the Lithuanian barons, together with Casimir mooted the possibility that the (1431) Švitrigaila-Russdorff treaty might be reincarnated with a Casimir-Erlichhausen treaty (see below). The Russdorf agreement itself was not anti-Polish per se. However, its renewal would have marked a break in the joint treaty of Brest which had been concluded later (1435). The proposal reflects the possibility of a serious rupture of the Lithuano-Polish union - a rupture which did not in fact take place (viewing events from the Jagiellonian perspective), but which is commonly ascribed by Polish and Lithuanian scholars to June 1440.

On January 61446 the lords spiritual and temporal of Poland gathered to hear Casimir's reply which was given by two Russian dukes, Vasily Krasny and Yury Semenich Ostrog, and four Lithuanian boiars, Jonas Nemira, Onacz namestnik of Brest, Andrius Davaina (Dowoinowicz) and Mykolas Mantautaitis (Muntoltowicz). The envoys were well chosen: the two Rus'ian dukes were close kinsmen of the grand duke's mother (a nephew and cousin respectively) and important landholders in the southern part of the Grand Duchy. Jonas Nemira had taken part in the Piotrków sejm of August 1445, while Onacz was the governor of an important trading post not far from the Polish border. He had been Casimir's supporter since the autumn of 1440. Davaina was governor of Grodno (also between Vilnius and Kraków) and an experienced negotiator with the Teutonic Order, as is clear from events of July 1442; Mantautaitis was the son of an influential Vilnius family, patrons of the Franciscans of that city.

Vasily speaks on their behalf (as their mouthpiece, 'organum'), stressing that: Casimir had not been sent from Poland, but had come into his inheritance as grand duke - inheritance is a commodity much stressed by Casimir throughout these negotiations - as indeed it was by Švitrigaila, Lengvenaitis and Mykolas; Lithuania is sufficient for him and he simply does not want to rule Poland as king, especially while Władysław may still be alive; thirdly, the Poles should not rush to elect a new king, for that would not be meet, especially since Poland is calm enough for the regents to continue to rule, as before. Casimir cannot stand by and watch another take over his (other) paternal inheritance, the Kingdom of Poland. ${ }^{43}$ The latter points repre-

${ }^{43}$ Długosz, 12-13. 
sent a not-so veiled threat to Małopolska: Poland was not calm and an additional Lithuanian attack was hardly welcome.

Oleśnicki celebrated a mass of the Holy Ghost to inspire the sejm. In reaction to the Lithuanian overture, the Poles declared that they would elect another candidate and send no more delegations to Lithuania. According to Długosz, at this point Sonka understood that the Lithuanians would kill Casimir if another becomes king (previous attempts on his life are referred to by the chronicler at this point), but she still urges election of another. Some feared that two candidates already had been elected (Władysław and Casimir) and that electing a third might be dangerous. A decision was taken to summon another sejm for March 27 at Piotrków. They decide to send two envoys, Krzesław Kurozwęcki of Lublin and Mikołaj Szarlejski z Ściborza of Inowroclaw to Casimir. These, it seems, were keener than the others on Casimir's election. ${ }^{44}$

On January 10 the houptman of Kaunas, Sudewoj, one of Casimir's commanders in the war against Moscow, presented an embassy to the Grand Master. The Teutonic Order was to be drawn more closely into events in Poland-Lithuania this time by Casimir rather than his rivals. Sudewoj reported on the outcome of the Vilnius sejm. The Grand Master rejoiced to hear that the king was well and announced that his wishes conformed with the wishes of the Lithuanian ponai. Sudewoj announced that Casimir had heard from his 'Rathe' that Russdorff and Švitrigaila had good relations (a reference to the treaty of Christmemel, 1431) and has sent him and Švitrigaila's man to discuss the possibilities of concluding a similar agreement. The Master promises to consult his men. Švitrigailą's man announced that his Master was faithful to Casimir, whilst Lengvenaitis's secretary wishes the Grand Master to intercede with Casimir to regain his confiscated patrimony. It is thus clear that Casimir enjoyed the support of his rival in Podolia and the south (Uncle Švitrigaila) and in Novgorod (Uncle Lengvenaitis - in a state of war with the Livonian branch of the Teutonic Order). This state of affairs was deliberately and unambiguously demonstrated to the Grand Master. Jonas Matusas offers two comments on Švitrigaila's involvement in these discussions. He reminds us that the Grand Duchy was not only Švitrigaila's 'fatherland' (tèvynè) but also his 'father's

${ }^{44}$ Długosz names Przedbior Koniecpolski, castellan of Sandomierz and Scibor Szarlejski - ibid. 13-14; however, in a contemporary report Krzesław is named as the first envoy - CESXV III, No.1, p.2. The mix up in the chronicle account is probably due to the fact that the envoys despatched after the March 29 sejm are not mentioned in Długosz: these were Przedbior and Ostrorog (see below). 
land' (tevišké). The old duke's behaviour should be interpreted best as a recognition of Casimir's right to inherit the Gediminid (Algirdian) patrimony. The Lithuanian insistence on respect for patrimonial rights runs through discussions. 'Patriotism' as a concept has very little significance here, pace Matusas. ${ }^{45}$ Significantly, perhaps, Gdańsk trade matters were also discussed during the embassy - a reminder of close contacts between the Prussian town and Casimir's administration.

In February 1446 we see an exchange of letters concerning a planned border meeting with the Teutonic Order. The Grand Master asks Casimir to help a Gdańsk merchant in dispute with Onacz of Brest. In his response to Sudewoj's embassy issued on February 14, the Grand Master remarks that he has held a secret meeting with 'wenig seyne gebietiger', since he has heard that 'der herre grosfurste welle ußsetczen lassen' the treaty of Brest. Note is made of the fact that Casimir has restored Lengvenaitis to his patrimony. A report on this embassy and its 'herte reden' was made to the Master of Livonia on February 16. News of this secret meeting, provoked by the Lithuanian side, may lie behind the rumours which spread through Poland that the Order was planning to renounce the treaty and attack Poland. Whether this was intended by the Lithuanians to form the basis of a new alliance in the wake of Casimir's rejection of the Polish throne, or was (more likely) simply an attempt to alarm the Polish council - and perhaps the Mazovians - and discredit the Order, such talk of renunciation dominated Polono-Teutonic relations until after Casimir's coronation ${ }^{46}$. The situation was especially dangerous for the Order, which, in accordance with clause 43 of the Treaty of Brest, would ipso facto release its subjects from their oaths of loyalty if it were to wage aggressive war on Poland (or Lithuania) - not an attractive prospect for the Grand Master who was accusing the Prussian League of breaking its oath to the Order. This card had been played with success by the Prussian Estates against Grand Master Russdorf in $1433^{47}$.

The Sejm's Envoys told Casimir that the Poles had every right to elect a king, especially after his 'mouthpiece' had announced his

${ }^{45}$ J. Matusas, Švitrigaila Lietuvos didysis kunigaikštis (Vilnius,199122), 162-3.

${ }^{46}$ Ibid. 15-16; OBA 9298, 9361, OF 16, 1108-11; Feb. 16 letter: $L U$ X, 299; see also A. Krupska, 'Udzielne księstwo mścislawskie pod rządami Litwy', Prace naukowe Uniwersytetu Ślaskiego, xviii (1971), 35-55.

${ }^{47}$ Die Staatsverträge des Deutschen Ordens in Preußen im 15. Jahrhundert, ed. E. Weise, I (Marburg, 1970), No. 181 § 44, p. 210; 1433: M. Burleigh, Prussian society and the German Order. An aristocratic corporation in crisis c.1410-1466 (Cambridge,1984), 142-3. 
rejection of their offer. They suggested he reconsider, since his position would be weaker, if another candidate were elected.

Casimir rejected this advice, repeating that there was still no certain news of his brother's death and stressing that he would oppose the election of another candidate. Długosz sees this as thirst for royal status which was restrained by the Lithuanians who feared Mykolas, the loss of privileges, loss of liberal donations made them by Casimir. That such donations had been made is clear from the Kniga danin, preserved in the Lithuanian Metrica. They feared losing all hope of regaining Lutsk and Podolia. The embassy returned unsatisfied and recommended proceding to a further election since there was 'no legitimate hope' that Casimir would reconsider.

On March 27 the Piotrków Sejm opened; ${ }^{48}$ Wincenty of Gniezno celebrated the inaugural Mass of the Holy Ghost and other lords spiritual and temporal took Communion in an atmosphere of possible discontent. On March 28 the lords declared that they would proceed to election to force Casimir's hand.

In place of the Lithuanian option, Oleśnicki proposed electing Frederick of Brandenburg as king. This plan won the support of Wincenty, Władysław of Wrocław and Andreas of Poznań. He was represented as a wise, Polonophone neighbour (and a grandson of Jogaila) who would build towns, regain control of Rus' and Podolia, defend Poland against Casimir and make the country the equal of all others. His experience in Bohemia and the Empire was stressed. However, the barons of Wielkopolska were not likely to favour the election of a dangerous neighbour.

Bishop Pawel of Płock did not favour the election of an alien and suggested instead Bolesław of Mazovia. Jan de Czyzow, Tęczyńksi, Górka and Jan Oleśnicki supported the Mazovian candidature. The vote was split vote and Tęczyński reported that the Lithuanians were afraid of Bolesław. The bishops changed sides and Bolesław'scandidature was accepted. This was enough to block Frederick of Brandenburg, but insufficient to pose a real threat to Casimir.

On March 29 Wincenty of Gniezno, Andrzej of Poznań, Jan de Czyzow, Górka and Jan Oleśnicki were chosen as envoys to go to Bolesław to summon him at Pentecost, if Casimir has not changed his mind to accept. Przedbior Koniecpolski and Stanisław Ostrorog were sent to Casimir to tell him that Bolesław would be elected if he refuses ${ }^{49}$.

${ }^{48}$ Dhugosz, $17-21$.

${ }^{49}$ Piotr Ostrorog according to OF 16, 1108-9. Since the Order's information refers to three envoys and we know that Ostrorog was Stanisław and not Piotr, it may be that the scribe has elided two names here. 
According to the Teutonic Order's information, Casimir did not send envoys to Piotrków, although Długosz mentions the presence of "levis nuncius Casimiri ducis" at the sejm. ${ }^{50}$ This seems to be the chronicler's means of explaining how Casimir could know of the sejm's outcome without admitting that the Polish nobles actually sent him yet another embassy. The bishop of Płock informed Bolesław of the outcome of the sejm in early April. It seemed that no one knew of the Order's good relations with the Mazovian or that, according to the Order's source, Bolesław and Casimir had come to an agreement over the former's possible election as king. The text itself is ambiguous and may be interpreted as meaning that Casimir has Bolesław's support and that he (Casimir) is ready to be elected king:

Also her is gelossen hatte mit den sendeboten der herrn von Polen. Ouch habe ich vornomen, das der grose furste mit herczog Bolken wol eyns ist und man vorsihet sich is werde seyn wille seyn, das her dirwelt ist.

On April 21-25 three Polish 'herren' were in Vilnius to speak with Casimir. ${ }^{51}$ A Livonian delegation arrived on April 23 to hear complaints that their men had seized property belonging to the bishop of Vilnius and to discuss their conflict with Polotsk and other Rus'ians. Gdańsk complaints were also scheduled for a hearing..$^{52}$

${ }^{50}$ Długosz, 20; OBA 9071 (XXI/a No.80), April 4 1446: "quam der Bisschoff von Ploczke und brochte seynen genode wore czeitunge, das seyne genode dirwelet were eyntrechtichlich von allen herren mit willen der ganczen gemeyne eyn konig czu seyn czu Polen und andere hn, die do gesant seyn in der botschafft czu seynen $\mathrm{g}$. die sullen hernoch komen ane sewmen und der furste harret irer alle seunden und mich dunket, das die dirwelunge sey wol gescheen und andirs nicht weis, das her ewern g. und des Ordens gancz frund sey. Ouch habe ich vornomen, das der grosse furste seyne sendeboten nicht gesant hot kegen Petirkaw czu den gespreche, der sich die herren von Polen yo vorsehen hatten czu komen. Also her is gelossen hatte mit den sendeboten der herrn von Polen. Ouch habe ich vornomen, das der grose furste mit herczog Bolken wol eyns ist und man vorsihet sich is werde seyn wille seyn, das her dirwelt ist".

${ }^{51}$ OBA 9079 (XVIa.25), April 30 1446: "wir am neisten donnrstage nach Osstern uffn abend ken der Wille sind gekomen und am freitage dornach fruh die gewerbe vorbracht und gewurben haben, die denn der herre Grosfurste frundlich uffgenomen und guttlich vorhort hat. Ouch so woren drey herren us Polan aldo, so das her uns uff die czeit nicht konde entscheiden bis uff den Montag dornach ... Sunder her sprach he muste mit den Polen ouch eynen tag halden, ader uff welche czeit das gab her uns nicht czuvorstehen ..."; Casimir's agreement with Bolesław see above n.50.

${ }^{52}$ OBA 9075; Gdańsk: OF 16 pp.1098-99. 
In April or May 1446, when the Master was resident at Marienburg, Casimir sent a messenger via Prussia to the Pope. In Marienburg this envoy asked the Order's leader to be 'participes molestie' along with Casimir and 'habere visionem', that is side with him over the double election (i.e. that he and not Bolesław should be crowned) and have audience with him. However, von Erlichhausen continued to be wary of committing himself openly to one or other side, saying that he wished to uphold the treaty of Brest, although he would meet the grand duke..$^{53}$ If one aspect of the Order's public policy throughout this election crisis is patently clear, it is the pains to which the Grand Master went to assure both the Vilnius and Kraków camps of his desire to be neutral. A practical expression of this balance can be detected in the gifts the Grand Master bestowed on the representatives of both sides: falcons, silver belts, hunting dogs and so forth. ${ }^{54}$

According to Długosz, Casimir and the Lithuanians feared civil war if Bolesław should be elected king and seek to appoint Mykolas as grand duke. Casimir, it is alleged, feared for his life as opposition to Goštautas' party became manifest. The grand duke told his mother and later certain barons that he had changed his mind and asked them to hinder Bolesław's election. Archdeacon Martin of Vilnius, it is alleged, secretly persuaded Casimir to accept throne.

In the run up to Parczew certain Polish barons also began to fear loss of their position under Bolesław. Sonka and certain barons, headed by Jan Pilecki, son of Jogaila's third wife from her first marriage, held a sejm in Belszice. There was fear of Lithuanian armed attack on Lublin and other eastern Crown lands. The sejm sent Piotr Kurowski to Casimir privately. Casimir's agreement to accept the crown was announced to the barons rushing to Kraków for the feast of St Stanisław.

At Kraków on May 8 Oleśnicki linked Małopolska's final decision on the change of direction announced at Piotrków with the decision of the Wielkopolska sejm to be held at Koło in June 1446. On May 23 the Grand Master wrote to Casimir concerning their meeting arranged for Whitsun; on the same day he wrote to Wincenty

${ }^{53}$ CESXV III p.5-6; for period when the master was at Marienburg in 1446, see K. Neitmann, Der Hochmeister des Deutschen Ordens in Preußen - ein Residenzherrscher unterwegs (Cologne-Vienna,1990), 114-18.

${ }^{54}$ For Goštautas: two falcons and a 'sunderliche briff' sent on Nov. 301446 with credence for Jenichen von Tergowitz and Hans Marschalk, who were touring courts, starting with Casimir: OF 16, 1154; for Wincenty's servant, Vecens Furman - see below n.59. 
informing him of the outcome of the Piotrków sejm in March. He knows that the crown was offered to Casimir and by default to Bolesław. He claims not to know of the final outcome but stresses that whoever becomes king, he will confirm the eternal peace with the new monarch. ${ }^{55}$

Oleśnicki, Jan Tęczyński, Jan Oleśnicki, Krzesław Kurozwęcki, the castellan of Lublin and others sent messages privately to Bolesław. This group of counsellors also sent envoys to the nobles of Wielkopolska meeting at Koło in June 1446, where the assembled notables received news of developments from Jan Pileczki. The dignitaries at Koło decided to send to Casimir and invite him to a sejm at Parczew on September 29. Envoys were not sent to Bolesław. In June central European events began to warm up, as the Emperor prepared for an invasion of Hungary. The archbishop of Gniezno sought the Grand Master's protection for his visit to St Barbara's shrine at Aldenhus and further travel to Marienburg. ${ }^{56} \mathrm{~A}$ sejm for Małopolska

${ }^{55}$ OF 16, 1108, 1108-10. "den Sontag Letare in der neehstendegangene vaste die herren, prelaten, woiwoden und inwoner des Reichs zcu Polan in grosser menige und gemeynen gescheffte willen des Reichs zcu Pyoterkaw versamelt seyn gewesen und mit eyner stymme und eintrechticher verliebunge beslisslich eyne tag als uff den Sontag nach Sunct Johanns Baptisten tag neestkomennde umb der Cronung eyns zcukumsstigen herrn koninges ken Crakaw verramet haben und das etliche merkliche und achtbater Sendtboten, als her Peter von Ostrorog und Przedborius von Conetczpol zcu dem \| herrn Grosfursten en zcu bitten und an em zcu ffurden, das her die irwelunge van em gescheen volborten und uff den genanten Sontag die Cron zcu empfohn ken Crakaw sich ffugen welle, ken Littawen geschickt seyn, und ap her denn solcher irwelung nicht volborten und ouch nicht kon welle, also denn solden merckliche sendtboten und dy gewegesten des Reichs sich zcu den irluchten ffursten, herrn Bolesslao herczogen in der Masaw, der mit eyner stymme und eintrechtiger verwillunge so es des herr grosfurste nicht uffnemen welle zcu eyne konige sey erweldt personlich ffugen und en bitten, das her die cron und beschirmunge des Reichs uffnemen ... das der herre grosfurste in solcher eintracht erwelt und das zcu em geschickt ist, haben wir mit sampt unsern gebietigern gancz gerne gehort, und das her ouch in solche erwelunge welde wolborten, die uffnemen sich zcu der cronunge ffugen und die cron empfahen were uns und unsern gebietigem eyne sunderliche freyde und gondenem solcher ere und herrschafft van ganczen herczen wol und hortens zcu male gerne und ap her denn eyn solchs ufflaen und nich uffnemen werde, so horen wir und unß gebietiger ouch zcu mael gerne das als denn der irluchte furste herrn Bolisslaus mit eyner stymme und eynmutiger verwillunge zcu dem Reichs zcu Polen erweldt ist ..." Grand Master to Archbishop Wincenty, May 23 1446, OF 16, p.1108-9.

${ }^{56} \mathrm{OF} 16,1119-20$. 
and Rus' was called at Nowe Miasto Korczin for the feast of the Assumption. This meeting was not attended by the bishops and Oleśnicki was (or pretended to be) ill. Under Sonka's influence they accepted the Koło resolution.

Casimir's cat-and-mouse behaviour with the Polish, and to a lesser degree the Lithuanian nobility, seems to have been a deliberate and very carefully played gamble (in the style of his father Jogaila) which forced the various parties in Poland to show their hand and realize that they were weaker than Casimir himself. Casimir as Jogaila's only living heir had no intention of surrendering his paternal inheritance to anyone, as he announced after his coronation that no separate grand duke would be sent to Lithuania. He waited carefully for his opponents to discover for themselves the inferiority of their position. He trapped the Teutonic Order in a ruse which strengthened his own position as a possible defender of Poland and Lithuania against neighbourly aggression, while at the same time exploiting discontent within the Ordensstaat.

From letters of August 29 and September 2, 1446 it appears that rumours were still spreading in Poland that the Order was preparing for war. The Grand Master denied this strenuously and repeatedly. It seems now that the Poles, who may have been intimidated by such rumours at first now used them against the Order by deliberately delaying in their confirmation of news that the Grand Master had not sought a dispensation from the treaty of Brest from the Council of Basel - Archbishop Wincenty was issued a papal announcement to this effect in September 1446 but informed the Master of his knowledge only in March of the following year. ${ }^{57}$ On September 1, 1446 at Sthum the Grand Master issued a safe conduct for his servant Arnolt von Morttangen to visit the Council of the Polish Crown including: 'dem erczbisschoff zcu Gneßen, Grosfursten zcu Littauwen, bisschoffe zcu Leslaw, den herczogen Vlotken und Bolislao und houptmann zcur Wille' ${ }^{58}$ From September 21 we know that the Order had planned to send envoy to Brest/Parczew to the grand duke and the Polish lords, although the Grand Master himself was too busy to come. A gift (in the form of a silver chain) was sent to Wincenty's man, Vecens Furman, presumably as a sign of a desire to maintain good relations ${ }^{59}$.

${ }^{57}$ OBA 9298 (xxv No.87), March 31447 with papal letter from Aug. 29 1446; the Council's letters of the same date to Oleśnicki and the Grand Master are published in M. Dogiel, Codex diplomaticus Regni Poloniae et Magni Ducatus Lituaniae IV (Vilnius, 1764), nos. 101, 102, pp.139-41.

${ }^{58} \mathrm{OF} 16,206-7$.

${ }^{59} \mathrm{OF} 16,1133-5$. 
In September 1446 under the shadow of a threat of Tatar invasion from the Lithuanian side, the Polish magnates foregathered at Parczew. Sonka was also there. The counsellors of Poland required Casimir to attend, as indicated by Piotr Kurowsky. Rumours were passed on to the Lithuanian side by a Polish nobleman, Andrzej Rohatyński, to the effect that the Poles were planning violence against the grand duke's party. Casimir agreed to come to Brest and no further. The Poles sent a delegation of at least fifteen lords to Brest from Parczew, where Oleśnicki and certain of his associates remained. From Długosz we see that the Crown delegation at Brest included the archbishop and wojewoda of Lwów, the bishop and wojewoda of Poznań, the castellan of Kraków and the chancellor and vice chancellor of the Crown of Poland. ${ }^{60}$ Długosz's account appears to be another example of his editing of details of events so as to make Casimir's election appear to have been achieved with the support of only a minority of Polish noblemen. At the sejm the Lithuanians demanded that Lutsk, Podole and Olesko should be Lithuanian. The Poles refused and threatened to go to Bolesław. Casimir changed his mind and the Poles offered him the crown, right to dispose of Lutsk, Podolia and Olesko, as Jogaila did during his reign to Spytko, Švitrigaila and Vytautas. He promised to respect Polish liberties and the coronation was set for June 24, 1447. Piotr de Sczekocin, vicechancellor of Poland received letters to this effect. ${ }^{61}$ Casimir removed Lomazy and Polubice from the Parczew tenuta and transferred them to the jurisdiction of Brest. The Mazovian candidate was not accepted, Długosz explains, because of sins of his fathers St Stanisław had been murdered by Bolesław, Conrad of Mazovia had invited the Teutonic Order to Poland. The Kingdom had been divided by Piasts, Długosz notes, and even Casimir III (the Great) was accused of repressive measures towards the clergy, divorcing his wife and drowning a priest.

On September 19 the plenipotentiary Polish sejm delegation gave Casimir a letter confirming his election and agreement to come to Kraków for his coronation; they acknowledged his right to 'tenere, habere et fovere' servants of either 'lingwagium' (i.e. Lithuanians or Poles), that he may dwell in or travel to Lithuania and Poland as he wished and not be hindered in this by any subject of any condition. Lewicki is surely right to note that this document represented a 'salvus conductus' along the lines of the letter which Jogaila

${ }^{60}$ Długosz names eight delegates; the account issued by the sejm of its agreement with Casimir was signed by 13 Polish lords, the names of six of whom coincide with Długosz's account - Lewicki, 'Wstapienie', 21-3, CESXV III No.4, p.6-7.

${ }^{61}$ Długosz 26-28; CESXV I. 2 no. 6. 
required from the Polish nobles before he came to Poland in $1386 .^{62}$ This then is the outcome of negotiations in accordance with the alternatives outlined in Grodno in October 1445.

This is the only document which clearly emmanates from the Parczew-Brest sejm. Anatol Lewicki in his study of Casimir's accession introduced a hypothesis to the effect that another proposal was presented to the Poles during the sejm by the Lithuanians, but this was later rejected. This text refers to a union of Poland and Lithuania effected by Casimir and an agreement over control of certain Rus'ian territories: Lutsk, Vladimir, Olesko, Ratno, Wyechlye, Lopaczyn and Podolia. The text is not dated, but refers to a period before Casimir had heirs of his body (therefore before his marriage of 1453). Casimir refers to himself as king of Poland (which he was not in 1446) and refers back to a 'union'. Such a union was confirmed by his coronation; the issue of a document, other than the Brest letter of September 19, is not strictly necessary. Lewicki's argument that the agreement could have been presented only in 1446 because it reflects great weakness on Poland's part is more than circumstantial. Severe disagreement with Lithuania over Podolia was still raging in 1451-53 when Poland was on the brink of war with the Order and Casimir faced open revolt in the Grand Duchy. Since by this time Švitrigaila was dead, the Rus'ian question was in need of discussion. ${ }^{63}$ The reference to the letter's being issued at Parczew (where Casimir was not in 1446) and the fact that he is called 'rex' rather than 'electus rex' (the style used in the 1446 document which precedes the text in its sixteenth-century manuscript copy) does not appear to be a scribal error or 'correction'. ${ }^{64}$

${ }^{62}$ CESXV III No.4, p.6-7; Lewicki, 'Wstąpienie', 23.

${ }^{63}$ Lewicki found an interesting undated document and fell to the temptation to force it to fit the 1446 situation. While it is possible that a later scribe 'corrected' a reference to the 'king-elect', on the whole the text reads like a declaration from King Casimir. The nineteenth-century legal historians' interpretation of the LithuanoPolish union, especially its fifteenth-century vicissitudes deserves re-examination. The election of Casimir as Grand Duke by the Lithuanians did not break the union, nor did it fundamentally change it (from the Jagiellonian perspective). Casimir was sent with Polish agreement and was made Grand Duke, a situation Władysław III accepted, retaining the earlier distinction between 'magnus dux' and 'supremus dux'. Casimir's tenacious hold on both realms reflects the intentions of Jogaila in 1385-6 which the old king could not sustain in the face of Vytautas's ambitions.

${ }^{64}$ Lewicki, 'Wstapienie', 23-26; for further analysis of this document, see S.C. Rowell, '1446 and all that' (Vilnius, forthcoming). There is one manuscript dated July 5, 1446, a charter for an obscure Polish family, which refers to Casimir as 'rex', but this is of highly dubious authenticity - Vilnius, MABRS F1-15. 
On December 2 the Order's mission to Casimir reports that Casimir had written to them concerning his election:

uns denn der herre grosfurste geschreben hat, das her erwelet und gekrig sey zcu eyne koninge zcu Polan und solle beyde lannd halden als Polan und auch Littawen. So haben wns unsern gebietiger und lande gancz gern gehort und ist uns eyn frundlich frewde, das her in seyn vaterliche Reich und lannde komen und dabey bleiben moge. ${ }^{65}$

The embassy then dealt with the border at Širvinta and Šventoji, and problems experienced by the Gdańsk merchant Arnd Vinckenberg.

According to a letter of credence issued on December 29, 1446 by the Grand Master, a certain Nicklus Wilken wanted to visit Švitrigaila and Lengvenaitis that winter 'in nemlichen seynen geschefften zcu ffugen.' At the same time the Master informed the Stadholder of Wielkopolska that the Order wanted peace with the Crown. ${ }^{66}$ It appears from a description of Wilken's report to the Master on his return from the Grand Duchy in March 1447 that the diplomatic aspect of the man's 'geschefften' was to discover what Lengvenaitis was planning to do in Novgorod. Wilken reports that Lengvenaitis required a safe conduct to attend Casimir's coronation on June 24, 1447 and that he would return via Prussia, Livonia and Pskov to Novgorod. Because the king-elect had restored his patrimony, Lengvenaitis was no longer so keen on regaining the governorship of Novgorod. The Order was planning to attack the city during Casimir's coronation and Wilken would be sent to Kraków in June to keep an eye on Lengvenaitis..$^{67}$ Therefore, the Grand Master's 'secret' correspondence concerning Lithuania was not directed against Casimir but intended to ascertain Lithuanian reaction to regional events. Lithuanian and Polish (Silesian) troops were garrisoned in Lutsk, probably for defence of Novgorod, which Lithuanian merchants were supplying with Prussian arms.

${ }^{65}$ OBA 9212.

${ }^{6} \mathrm{OF} 16,1160-1$.

${ }^{67} L U$ X, 303 p. 209-10 (OF 16, 367-8). The Order's plans to attack Novgorod add an extra dimension to the diplomatic flurry surrounding Casimir's coronation. Throughout the spring of 1447 the grand master and the head of the Livonian branch of the Order sounded out preparations for this war. Rumours reached Prussia that Novgorod would receive assistance from Bohemia, Poland and Silesia (also to be represented at Casimir's coronation) - $L U$ X, 314 pp.216-7, April 10 1447. Investigations would show that these troops (600 horse) were in Lutsk (i.e., Švitrigaila's centre of power) - LU X, 333 p.228, May 81447 . The Lithuanian princes seem to have been planning a joint defence of Novgorod. 
At the beginning of 1447 Casimir sent his noble servitor Daukša on an embassy to Boris Andreevich of Tver' to assuage disputes with Tver' (and Muscovy). Border regulation and trade disputes were the subject of Vako and Byler's embassy to the Order in February. These Kaunas officers asked the Master to intercede with the commander of Ragnit in the case of the merchant Thomas Samed whose shipment of Nuremburg armour had been impounded by the Order's customs' men, acting on suspicion that the goods were intended for consignment to Novgorod. ${ }^{68}$

By March 5 the archbishop of Gniezno was ready to inform the Master that he had received Casimir's letter of agreement to coronation. At the same time Wincenty sent the Master the letter he had received from Basel concerning investigations of (inaccurate) rumours about the Order's attempt to squirm out of its obligations under the treaty of Brest. In sum, several Polish prelates had written inquiring whether the Order had asked for permission to renege its oath to uphold the Treaty of Brest. The Council has scanned its records and found no trace of such a plea or its acceptance. A general enquiry among delegates also draws a blank. This would have been "non solum sennarium belli sed incendium fore sicut solvere vinculum, quo federa pacis tenebantur". It is the council's duty to defend peace - 'curavimus ut tu, qui in inclito regni Polonie principatum tenes, ipsius gentes et populos de hiis rebus reddas attentos' ${ }^{69}$

On May 2 1447, at Vilnius, Casimir issued a charter to the lords spiritual and temporal, barons, boiars and burghers of Lithuania, Rus' and Žemaitija, as the true, lawful heir and their natural lord. Acceptance of this charter was the clearest confirmation of Casimir's domination in the Grand Duchy. The Lithuanian nobility (of all ranks both temporal and spiritual) and burgherate gain the same rights as those already won by their Polish counterparts. It is worth noting the explicit mention of townsmen in this context. Ecclesiatical foundations had their rights confirmed too. The Grand Duke reserved the right to appoint to vacancies, promised to appoint a subject of Grand Duchy, if suitable candidate existed, and only if no suitable canididate were available would he appoint 'alterius nacionis personam'. There would be no punishment except in accordance with Catholic law in open court in the presence of both the defendant and the plaintiff with sentence being passed in accordance with Polish law. Only the defendant was to be punished, that is, no kin would be punished in a guilty man's stead, unless also they took part in crime. An exception

${ }^{68}$ See above n. 19.

${ }^{69}$ OBA 9298 No. 2. 
to this rule was punishment for treason. The nobles won the free right to leave their land to seek prosperity or practice soldiery, except to enemy territory. However, others were to compensate for dues they could not pay in their absence. Casimir confirmed patrimonial holdings and donations (as in the case of Lengvenaitis and Švitrigaila, but not Mykolas) and granted his subjects the right to dispose of their inheritance. In all these clauses we see the strengthening of noble rights against grand-ducal power and the confirmation of Catholic privileges, an important factor in the 1440s as the Union of Ferrara-Florence was proclaimed in eastern and central Europe. Lithuanian borders were to be as they were in Vytautas's day and no aliens were to hold castles, office or dignities within the Grand Duchy.

On May 3 Casimir reconfirmed the basis of relations between Polotsk and Riga which had been strained for over a year. On May 14 the Master wrote to Livonia of plans for June attack on Novgorod, noting that a Polish-Lithuanian force was reported to be coming to aid the Livonians. Mykolas was reported to be en route to Brest to meet Casimir. ${ }^{70}$

On Whit Tuesday the Master announced that he would not be able to attend Casimir's coronation in person, but that instead he would be represented by two commanders, Ludwik v. Erlichhausen of Mewe and Heinrich v. Plauen of Elbing. On Trinity Sunday, June 4,1447 , the Master issued instructions for his envoys to the coronation, stressing that Casimir should publish information from the Basel bull to the effect that the Order never tried to squirm out of the Treaty of Brest..$^{71}$

In early June Casimir arrived in Brest where he spent a few days with Lithuanian notables. The Lithuanian party then proceeded to Lublin where it was met by Szekocin, Sonka's man. On June 17-8, the entourage reached Sandomierz where it joined up with Queen Sonka. The royal group then travelled via Pokrzywnica (Monday June 19), Polanyec (June 20) and Korczin (June 21) where it met up with Oleśnicki and Tęczynski. Having passed through Podalany and Proschowitz on June 22, Casimir entered Kraków to popular acclaim on Friday June 23. In the afternoon he was fêted by members of the University, Archbishop Wincenty and Bishops Zbigniew (Kraków), Andrzej (Poznań) and Pawel (Płock). He entered the castle, visiting the relics of St Stanisław before moving on the the Hall. The following day, June 24, saw the arrival of the dukes of Mazovia in regal splendour with a retinue of a thousand retainers.

${ }^{70} L U$ X, 331, pp. 225-6; 336, pp. 230-31.

${ }^{71}$ OF 16, 1186-7; OBA 9361 (xxv.72). 
Sunday June 25 was set aside for the coronation. The new king was crowned by the Polish primate, Wincenty of Gniezno with the assistance of bishops Zbigniew of Kraków and Władysław of Wrocław and attended by other Polish bishops. Sonka, the dukes of Mazovia, Władysław and Bolesław of Cieszyń, Wacław of Raciborz, Wacław of Oświęcim witnessed the solemnities. Two members of the Teutonic Order, Heinrich v. Plauen of Elbing and Ludwig v. Erlichhausen of Mewe represented the Grand Master, who was absent, planning among other things his assault on Novgorod. The Lithuanian side was represented by Švitrigaila, Yury Semenich, Vasily Olelkaitis, Vasily Krasny and the boiars Senko Gedegaudaitis, Andreas Sakaitis (a group which features again in Lithuanian delegations to Polish sejms ${ }^{72}$ ) and 'plures alii'. Barons from Bohemia, Moravia and Silesia were also in attendance - unexpectedly, according to Długosz, but quite expected, according to the Order's information. ${ }^{73}$ Monday June 26 saw a squabble among the dukes of Mazovia and bishops over precedence in the royal entourage. The King left to receive the Teutonic Order's embassy. The following day village women protesting about service demands made upon them disrupted worship in the Wawel cathedral.

On June 29 Casimir's envoys met the Order's representatives to discuss swearing to the eternal peace. The new king was represented by Piotr Odrowąz, wojewoda of Lwów, Stanisław of Osterog and Sawn wojewoda of Czersk. Most notable here is not the presence of former sejm envoys to Casimir, but the involvement of a functionary subject to Bolesław of Mazovia.

The Order complained that some Poles had accused the Knights of asking the Lithuanian herren to unite against Poland, but this is not true. Casimir says that he has no knowledge of such a rapprochement. The Knights also remind Casimir that the Council has sent confirmation that the Order had not sought to break the treaty of Brest and ask the king to make this clear publicly. ${ }^{74}$ This tactic is in keeping with instructions issued to the envoys after Trinity Sunday, although the alleged rumours of the Knights' approaching the

${ }^{72}$ As in 1453 - Długosz, 135-6.

${ }^{73}$ Długosz, 33; $L U X$, No. 314, p. 216-7.

${ }^{74} \mathrm{OBA} 9361$, fo. $5^{\mathrm{rvv}}$ : 'Item am selbigen montage sageten sye ym: Durchlauchter furste und grosmechtiger koening, eyne boreuchtunge ober unseren Orden ist awsgegangen ym Reyche czu Polen und yn ewer koeninglichen gnoden Cronen, wye das unser homeyster und wir alle sulden den ewigen frede wellen brechen und sulcher eyde, dye wir denne gesworen haben ober den ewigen frede, gesucht sulden haben ym concilio uns czu entpinden. Wer unserem homeyster, unserem orden und unserem landen eyn sulchs czu geleget hot [d]er ist nicht unsers 
Lithuanians to form an anti-Polish alliance are not mentioned in the instructions. The proposal concerning a renewal of the Russdorf treaty came from the Lithuanian side, as we have seen, and there is no trace in surviving records that the Order took an initiative with the Lithuanian nobility. Of course the unanswerable question also arises as to which noblemen could be envisaged here: not Casimir and Goštautas's faction and probably not even the Žemaitijan supporters of Mykolas. The Order's man who sought to visit Švitrigaila and

ordens und unser lande frunth gewesen, wenne unser homeyster, seyn orden und seyne lande sulchen ewigen frede stete und pfeste abegot wil halden wellen und so habe w[ir] hyr e[yn] bulle vom concilio dorynne ewer koenicliche gnode wol hoeren wirt, ab man unserem homeyster, seynem orden und seynem landen recht adder unrecht gethon hot, und bitten ewer koenicliche gnode czu lesen losen. Die bulle wort gelesen etc.

Entwort des herren konynges: Her hette do von nye gehort und wuste ouch wol, das es nicht were, und seczte ouch keynen glouben doroff, das wir eyn sulchs gesucht hetten und wurde her eyn sulchs erfaren, her welde es selber dem herren homeyster schreyben etc. \| Item am selbigen montage wurben sye ouch an den herrn koenig: Durchlauchster furste und grosmechtiger koening, unserem homeyster ist wol vorkomen, wye das etliche herren awß der cronen von Polen offenbar solden gerehet haben, wye das unser homeyster, unser orden und unser landen solden gesucht haben an den littawischen herren sich mit ehen czu vorbynden ober dye crone von Polen. Wir czweyfelen nicht eweren gnoden ist do von wol wyssentlichen denne ewe koenigliche gnode ist großfurste und yn den landen gewest und noch großfurste seyt und ewer konigliche gnode weýs wol, ab wirs gesucht haben adder nicht, und ab man unserem homeyster und seynem orden, der methe recht adder unrechte thut. Zunder dye eyn sulchs sagen dye seyn unsers homeyster seynes ordens und seyner lande frunth nicht und welde got, das wir den mochten sehen der sulche wort retthe. Wir welden das alzo vorantwerten, das ewer koenigliche gnode sehen woerde, das man unserem homeyster, unserem orden und unseren landen ungutlich dorane thethe etc.

Entwert des herren koenyges: Wir wyssen wol, das es nicht geschen ist, das ors gesucht habet und haben ouch do von sye gehort und uns ist nicht wyssentlichen do von denne wir haben tage mittenander gehalden, do eer ouch bey seyt gewesen, wir haben es nye hort gedencken und ouch von nyekeynem littawschen herren erffaren, do es an gesucht weren, und sprach czu den polenschen herren. Eer polenschen herren das hort eer wol, das eer sulch wort loset awßgehen, yo wen es dorczu koemmet, so wellet eers nicht bekant seyn und wellet euch gute fru[n]t vorterben czu vorderste mit den littawschen herren, dye ewer gute frunde seyn und ouch mit den herren von Prewßen mit den eer czu guter eyntracht seyt gekomen. Es wer besser das eer eyn sulchs lyst und menget nicht gute fru[nd]. Doroff der erczbisschoff sprache: Herre koenig, sulcher wort were nw nicht noet czu dusser czeyt. Der koenig entwerte und sprach: Es ist alle wege noch dye worheyt czu reden.' 
Lengvenaitis at the end of 1446 did so with Casimir's knowledge and was interested primarily in potential responses to policy concerning Novgorod (as we have noted above).

Life in the Grand Duchy continued according to preordained plan. On June 25 the bishop of Vilnius and the starostas of Trakai, Kaunas and Vitebsk met the Livonian brethren to inspect the Žemaitijan border (across which the Prussian army was planning to move in support of Livonia against Novgorod). The Livonians began to complain that the border should be as it was when Žemaitija was subject to the Order, but it was accepted that this would counter ... the treaty of Brest. ${ }^{75}$ After his coronation Casimir went on progress around Wielkopolska before returning to Lithuania where he would spend most of the next few years. In Poland government was dominated by Sonka and the Wielkopolskan nobility. ${ }^{76}$

The autumn of 1447 was enlivened by the Order's attack on Novgorod. The Master reported on the opening of the war to a German commander (at Botzen an der Etsch) in September, noting also the coronation of Casimir and his retention of both realms.

The sting of the dispute with Mykola had been drawn by events of 1444-46, but Casimir was in no mood to be as obliging in this regard as he had been with Lengvenaitis and Švitrigaila. In June 1447 Mykolas requested a special interview with the grand duke. A letter of credence was issued for this purpose on July 1. On July 27 the prince met his second cousin at Kalisz, where he asked for his patrimonial lands of Trakai to be restored to him. However, the newly crowned king felt confident enough of his position to decline his kinsman's request. Mykolas returned to Prussia to plan his next move - a Tatar invasion of Podolia. ${ }^{77}$ By September 11 the Master had received Casimir's request to block Mykolas' passage through Prussia and thus instructed the Livonian Master. The Lithuanian and Žemaitijan border transit points were being strengthened. In fact Mykolas' servant did apply for permission for his lord to cross through Prussia but without success. Skalvian sources revealed that the prince had crossed the wildnes and the river Širvinta into Žemaitija. ${ }^{78}$ In short, Lithuanian political life continued on course through the coronation crisis and beyond. The bogeyman depicted by historians in the form of Mykolas did not cease to follow his own course after

${ }^{76} \mathrm{LU} X, 359$, p. $247-9$.

${ }^{77}$ Fałkowski, Elita, 50-1, 77-8, n. 16.

${ }^{78}$ A. Kopystiański, 'Książę Michał Zygmuntowicz', $K H$ xx (1906), 74-165.

${ }^{79} L U$ X, 379 p.258-60 (grand master to Livonian master, Sept. 11 1447); commander of Ragnit to grand master, Sept. 19 1447, OBA 9394. 
Casimir refused to be reconciled with him in the summer of 1447 but his camp was no longer strong enough to threaten the grand dukeking's position.

In short: when Władysław III died at Warna he left behind him a straggling monarchy faced by problems at home and abroad. In Lithuania the Vilnius faction was already in control of the Grand Duchy, after winning over the most serious opposition factions which had almost exhausted themselves in armed conflict with the Casimirfronted, Goštautas-led court party in 1440-42. Internal competition within Lithuania was exploited by Casimir to press his own patrimonial interest from 1445 onwards. Casimir worked closely with his mother, Sonka, who virtually governed Poland, but in Lithuania the young Jagiellonian began to form his own policy after five years or so of difficult, but useful tutelage. His patrimonial outlook dominated his reaction to the Małopolskan attempt to take him under their wing. Švitrigaila and Lengvenaitis were both willing to accept Casimir's overlordship when he accepted their right to retain their patrimonial lands. They were elderly men who had come to terms with the fact that they would not take over Algirdas's legacy from the Jagiellonian line. A decade or more of civil war had shown them this. A similar confirmation of Mykolas paternal heritage was impossible - it would give a relatively young competitor (unlike Svitrigaila and Lengvenaitis) a good material base (including the commercial centre of Trakai) and a foothold on the western lands of 'Lithuania propria'.

Casimir confirmed Lithuanian privileges, especially those of the nobility, promising to safeguard their access to land and office in the Grand Duchy. The main theme running through these legal documents is to preserve local traditions from the influence of foreign administrators who threaten the groups forming within Lithuania with extra competition. This same fear of outside competition is clear in Lithuanian commercial practice (judging by the complaints of Gdańsk merchants in Kaunas and Vilnius) and in the Grand Duchy's blossoming (Catholic) religious life. Such particularist fear would destroy the chances of the Union of Florence to take a hold in the Grand Duchy by an unwillingness to admit Orthodox competition to enter Catholic ecclesiastical spheres. From the Poles Casimir gained recognition of his right to this inheritance and his right to reside and travel where he will. There was probably no formal agreement over disputed Rus'ian lands. Throughout the game of cat and mouse Casimir and his mother expose the weakness of the Małopolskan élite. Fear of the Order is exploited by Casimir and his faction. 
Mazovia is dealt with by calling on recent military defeats and dynastic connections. The Teutonic Order is paralysed by exploitation of rumours concerning an attack on Poland and underhand renegal of the Treaty of Brest which gives strength to internal dissent (the Prussian League). The Polish side appears to have grasped the blackmail politics towards the Order. After the coronation he is asked to publicly defend the Order against charges of plotting against Poland (and Lithuania). The new king travels to Wielkopolska, main centre of Sonka's support, before returning to Lithuania where he continues to strengthen his position in Rus'ian policy. Casimir would spend most of his time in Lithuania until the Polish war with Prussia began in 1454. The coronation negotiations mark Casimir's emergence as a diplomat capable of holding his own in Lithuania, the beginning of the move out of Goštautas's shadow. He keeps both his patrimonies and maintains the integrity of the Grand Duchy, permitting no partitions or a reduction to a patchwork of duchies such as made up the Polish Crown. As in the Charter of Vilnius, May 2, 1447, the principle of inheritance and the right to dispose of inheritance triumphed. The Małopolskan barons failed to introduce territorial parcelisation of the Grand Duchy, the Vilnius barons were unable to keep Casimir completely to themselves, even though other possible faction leaders were reconciled with Casimir or put aside (Mykolas). The Lithuanian nobles, especially the Goštautas- and Kęsgaila-dominated Vilnius court party were not the childish rejectors of certain cultural norms which they could adopt from Poland, as the Bychowiec Chronicle implies in its description of the alleged rejection of Polish armorial devices. They were participators in common cultural and religious enterprises - patronage of the University at Kraków and the confraternity of St Mary - and were greedy for equal rights before the Grand Duke with the Polish gentry before the king, as is clear from the articles of the Charter of Vilnius. What they did not desire was a loss of hard-won advantages - either as a result of internal competition, outsider rivalry or a dictatorial grand duke-king. In the 1440s the Lithuanian nobility was only just beginning to consolidate its nascent opinion that the Grand Duchy was its political patrimony too. It is in patrimony, not patriotism that the key to understanding the mid-fifteenth-century pluralistic Grand Duchy and Lithuano-Polish relations, especially the coronation election of 1445-47 lies. It is just such a concept which Oleśnicki and Długosz were loath to accept on Casimir's part, hence the coronation crisis narrative which still dominates evaluations of the events of 1445-47. 